ECONOMIC GROWTH CENTER

YALE UNIVERSITY

P.O. Box 208629

New Haven, CT 06520-8269

http://www.econ.yale.edu/ egcenter/

CENTER DISCUSSION PAPER NO. 898

\title{
CONSUMPTION SMOOTHING? LIVESTOCK, INSURANCE AND DROUGHT IN RURAL BURKINA FASO
}

\author{
Harounan Kazianga \\ Columbia University \\ (hk2252@columbia.edu) \\ and
Christopher Udry
Yale University
(udry@yale.edu)

November 2004

Notes: Center Discussion Papers are preliminary materials circulated to stimulate discussions and critical comments.

Harounan Kazianga received financial and technical support from the Economic Growth Center, Yale Univrsity and the Rockefeller Foundation Grant for Postdoctoral Research on the Economics of the Family in Low Income Countries. Christopher Udry acknowledges support from the Pew Charitable Trusts and the John D. and Catherine T. MacArthur Foundation.

This paper can be downloaded without charge from the Social Science Research Network electronic library at: http://ssrn.com/abstract=620742

An index to papers in the Economic Growth Center Discussion Paper Series is located at: http://www.econ.yale.edu/ egcenter/research.htm 


\title{
Consumption Smoothing? Livestock, Insurance and Drought in Rural Burkina Faso
}

\author{
Harounan Kazianga \\ and \\ Christopher Udry
}

\begin{abstract}
This paper explores the extent of consumption smoothing between 1981 and 1985 in rural Burkina Faso. In particular, we examine the extent to which livestock, grain storage and interhousehold transfers are used to smooth consumption against income risk. The survey coincided with a period of severe drought, so that the results provide direct evidence on the effectiveness of these various insurance mechanisms when they are the most needed. We find evidence of little consumption smoothing. In particular, there is almost no risk sharing, and households rely almost exclusively on self-insurance in the form of adjustments to grain stocks to smooth out consumption. The outcome, however is far from complete smoothing. Hence the main risk-coping strategies, which are hypothesized in the literature (risk sharing and buffer stock), were not effective during the survey period.
\end{abstract}

Keywords: Livestock, consumption smoothing, permanent income hypothesis, precautionary saving, risk sharing

JEL codes: D91, O16 


\section{Introduction}

Rural households in developing countries face substantial risk. Households living in these risky environments have developed a range of mechanisms to shield consumption from this risk, including income smoothing, self-insurance, and social insurance arrangements. There has been a good deal of work in recent years that examines the effectiveness of these formal and informal risk-sharing and consumption-smoothing arrangements (e.g. Alderman and Paxson, 1994; Fafchamps and Lund, 2003; Jalan and Ravallion, 1999; Townsend, 1994). The overall conclusion of this research is that most households succeed in protecting their consumption from the full effects of the income shocks to which they are subject, but not to the degree required by either a Pareto efficient allocation of risk (within local communities) or by the permanent income hypothesis (over time).

We examine the consequences of severe income shocks generated by drought for food consumption of a sample of farming households in rural Burkina Faso. We find evidence of very little consumption smoothing. There are large fluctuations in aggregate consumption that closely track the aggregate changes in income associated with the drought and subsequent recovery. There is no evidence that livestock served as an effective buffer stock during this period, nor was there significant use of financial markets to smooth these aggregate shocks. Village-level risk pooling mechanisms were not effective. Conditional on aggregate shocks, we show that household consumption closely tracks the substantial idiosyncratic shocks to household income. None of the main risk-coping strategies that are hypothesized in the literature were effective during the crisis period we examine.

In the context of the Sahel region of West Africa, primary among these hypothesized mechanisms is the use of livestock as a buffer stock to insulate their consumption from fluctuations in income ${ }^{1}$. Yet empirical studies have consistently found a small or insignificant response of livestock sales to shocks in other income streams (Fafchamps, Udry, and Czukas, 1998; Fafchamps and Lund, 2003; Hoogeveen, 2002). This pattern of results suggests that net livestock sales may not compensate for losses in income from other sources. In the specific context of Burkina Faso, Fafchamps, Udry, and Czukas (1998) show that during some of the worst drought years in the recent history of the

\footnotetext{
${ }^{1}$ See for example Famine Early Warning System (1999) for how actual policy making is based on this assumption.
} 
region, livestock sales compensated for at most between 15 and 30 percent of income fluctuations. Yet livestock holdings reported by most households at the end of the survey were large enough to compensate entirely for their income fall ${ }^{2}$.

In this paper, we examine three possible explanations for the apparent inconsistency between the commonly-shared belief that livestock is used as a buffer stock and the finding that there is little response of livestock sales to income shocks. First, it is conceivable that households were able to smooth consumption through other mechanisms, such as risk sharing or buffer stocks other than livestock. Empirically, this hypothesis implies that income shocks had little effect on consumption changes. Yet we find the contrary: during this crisis period, households' consumptions fell and rose with their incomes. Second, it is possible that the dynamics of livestock prices discouraged the use of livestock as a buffer stock. In particular, livestock mortality during the drought and reduced pressure on common grazing land afterwards may have resulted in higher expected prices in subsequent periods. This would raise the returns to current savings and reduce current consumption. However, we show that even comparing across households within villages (who share the same future price paths), those households who suffered idiosyncratic negative income shocks made no additional use of livestock sales to buffer their consumption. Third, liquidity constraints and a strong precautionary savings motive at low levels of asset holdings, particularly when combined with the need to maintain a reproductive herd may resulted in positive livestock holdings as long as consumption was at least above subsistence level. We cannot reject this hypothesis as an explanation for the minimal consumption-smoothing we observe.

The paper is related to two main threads of literature. First, the paper is related to a growing literature which focuses on poor households' ability to draw on their savings or to enter in informal risk sharing arrangements to smooth consumption. In recent years, a large body of empirical research has consistently found that households in poor developing areas are able to protect consumption against a substantial fraction of income risks, but that full insurance is not achieved ${ }^{3}$.

\footnotetext{
${ }^{2}$ For West Africa's Sahelian countries (Burkina, Mali, Niger), livestock is one of the main sources of export revenues. Thus, the role of livestock as a buffer stock may also have macroeconomic implications.

${ }^{3}$ We can not here provide a review of this extensive literature. See Kinsey, Burger \& Gunning, Jalan \& Ravallion, Ersado, Alderman \& Alwang, Attanasio \& Szekely, Hoogeveen, (Alderman and Paxson, 1994; Townsend, 1994) (Alderman and Paxson, 1994; Bardhan and Udry, 1999; Kinsey, Burger, and Gunning, 1998; Jalan and Ravallion, 1999; Attanasio and Szekely, 2004) for example. Dercon (2004) provides a useful recent entry into the literature.
} 
Second, the paper is connected to the use of assets as a buffer stock when there are credit constraints (Deaton, 1991, 1992a; Banks, Blundell, and Brugiavini, 2001; Carroll and Kimball, 2001; Carroll, 1997). Deaton shows that households subject to borrowing constraints are able to smooth consumption with relatively low asset holdings. He proposes an inter-temporal model that incorporates a stochastic labor income and a non-productive asset (cash or grain on hand). In this model, even in the complete absence of financial markets, prudent households may accumulate and draw down stocks of physical or financial assets to maintain consumption levels that vary little from year to year. Substantial changes in consumption arise only when stocks of assets are drawn down to near zero, which may happen infrequently. Moreover, it is not necessary that asset holdings be large relatively to income. For instance, simulation exercises show that for a household holding an average stock of asset value less than the standard deviation of income, consumption variation is half that of income (Deaton, 1992a, p.257).

Rosenzweig and Wolpin (1993) depart from Deaton (1991)'s initial formulation by allowing a productive asset. In the context of rural India, bullocks are used as source of power in agricultural production, but can also be sold to smooth consumption in the face of income shocks. Therefore, consumption is smoothed at the cost of crop production efficiency. The authors find that borrowingconstrained households keep on average half of the optimal level of bullocks.

However, unlike Rosenzweig and Wolpin (1993) we explore livestock as a buffer stock in the context of the WASAT, where animals are mostly used for (sales) consumption purposes rather than as a source of power in agricultural production. Therefore we focus more on the price dynamics and the livestock production processes which govern the offtake decisions and hence the ability to use livestock to smooth consumption. We find little direct evidence of the use of asset stocks to smooth consumption. However, there is evidence that households either have a precautionary savings motive, or are concerned about liquidity constraints that might bind in the future. We find that households whose landholdings make them more subject to future income fluctuations save more.

The second section describes the survey and summarizes the data used in the analysis. The third section examines the degree of consumption smoothing by the sample households. The fourth 
section explores how exogenous income shocks affect herd management in the context of the Sahel. The fifth section concludes.

\section{Survey description and context}

\subsection{Survey and descriptive statistics}

The data for this paper were collected in rural Burkina Faso between 1981 and 1985 by the International Crop Research Institute for the Semi-Arid Tropics (ICRISAT). Approximately 25 households were randomly selected in each of six villages in three distinct agro-climatic zones for the survey. These zones vary in soil quality, annual rainfall patterns, and population densities. The Sahel in the north is characterized by low annual rainfall (480 $\mathrm{mm}$ per year on average), sandy soils, and low land productivity. The Sudan savanna has low rainfall $(724 \mathrm{~mm})$ and shallow soils. The Northern Guinea savanna in the southern part of the country is the most productive of the regions and has relatively high rainfall $(952 \mathrm{~mm})$. The survey collected detailed information on crop production, asset holding and asset transactions, transfers (money and in kind), grain stocks, consumption, and daily rainfall (Matlon, 1988; Matlon and Fafchamps, 1989).

The survey timing is of great importance to this study. The survey spans a period which was marked by some of the worst drought years ever recorded in the region. As shown in table 1, in each of the six villages, rainfall recorded during the survey period was consistently below its long run average. Because of the predominance of rainfed agriculture, these rainfall fluctuations translated into enormous aggregate shocks. Figure 1 shows historical rainfall pattern in the region. It is apparent that the survey took place in the middle of a severe drought period and coincided with some of the lowest recorded rainfall levels for the region. Time series of annual rainfall in the west African semi-arid tropics are stationary, with the exception of a large downward shift in the mean of the distribution that occurred sometime in the late 1960s (Tapsoba, Hache, L. Perreault, and Bobee, 2004; Barbe, Lebel, and Tapsoba, 2002; Nicholson and Grist, 2001). By the time of the survey, households would have had more than a decade to incorporate the occurrence of this shift in the mean of rainfall into their expectations. 
The ICRISAT survey did not collect consumption data directly until during the last two cropping years of the survey, i.e. 1984 and 1985. Detailed data on the use (net sales and gifts) of each crop (collected weekly), as well as seed use and stocks at the onset of each season are, however, available. Each plot owner was interviewed separately. This information can be used to generate household consumption data using the "flow accounting" identity (see Ravallion and Chaudhuri, 1997). The same consumption data have been used by Reardon, Delgado, and Matlon (1992). In our context, this method has both an advantage and a drawback. The main advantage is that a measure of own consumption of food, presumably the largest fraction of total household consumption, is readily available. This is particularly useful since households tend to underreport own consumption (Ravallion and Chaudhuri, 1997). The main drawback is that a spurious correlation between income and consumption may rise because of similar measurement errors in both variables (Ravallion and Chaudhuri). We believe, however, that the instruments that we use allow an appropriate handling of this type of measurement error ${ }^{4}$.

The sample consists of very low-income households. Table 3 shows that annual income and consumption per adult equivalent is less than CFA 20,000 most of the time. If evaluated at the exchange rate of the time of the survey (CFA 250 for $\$ 1$ ), this consumption level corresponds to $\$ .25$ per adult equivalent per day. Even if we suppose that households were spending the same amount on non-food items (which is exaggerated) consumption would be far below the conventional $\$ 1$ a day adopted for global poverty measures.

This level of poverty is associated with very low levels of food consumption on average, and during the drought years many of these households experienced dramatic declines in their already inadequate consumption. There are 184 household-year observations with negative consumption growth and for 167 (91 percent) of those observations, livestock holdings were positive. For the $20^{\text {th }}$ percentile of these observations with negative consumption growth, observed food intake was equivalent to 1770 kilocalories per adult equivalent per day. This corresponds to only about 60 percent of the recommended level of 2850 kilocalories for a moderately active adult (FAO-WHOUNU, 1985). If each of these households had sold their livestock and purchased food at the local

\footnotetext{
${ }^{4}$ Our identification strategy, which relies essentially on rainfall variation, is discussed later.
} 
prices, their average consumption would have increased to 3300 kilocalories per adult equivalent a day. Calorie intake would have exceed the the recommended level in 43.5 percent of the cases ${ }^{5}$. To sum up, the actual food intake data portray households with extremely low food intake who choose to hold onto their livestock at the cost of further deterioration of their already inadequate nutrition ${ }^{6}$.

\section{$2.2 \quad$ Shock measures}

In this section we use the data on rainfall deviations and the allocation of cultivated land across soil types to recover income shocks. To begin, village average income and consumption growth are presented in figure 2. Two main features of the data are apparent from this figure. First there were enormous income shocks over the period (as expected by inspection of the rainfall data). Second, consumption tracked income closely at the village level; there is little evidence of effective smoothing of consumption over time in the face of aggregate shocks.

To proceed further, we quantify these shocks. We exploit the strong dependence of farm outcomes on rainfall in the WASAT environment (Fafchamps, Udry, and Czukas, 1998). To the extent that production on different types of land responds differently to similar rainfall levels, and land allocation is made at the beginning of the season when rainfall level is unknown, the cross-product of soil types and rainfall realization provides a measure of the income shock which is both exogenous and unanticipated. We estimate

$$
y_{i t v}=z_{i t v} \alpha_{1}+\left(X_{i t v}^{\prime} \otimes F_{v t}\right) \alpha_{2}+\gamma_{t v}+\gamma_{i}+\varepsilon_{i t v}
$$

where $y_{i t v}$ is the crop income of household $i$ at time $t$ in village $v, z_{i t v}$ is a set of household demographic variables, $X_{i t v}$ represents the allocation of plot areas to specific soil types, $F_{v t}$ is current rainfall deviation from its long run mean measured in each village, $\gamma_{t v}$ is a village-year fixed effect, $\gamma_{i}$ is a household fixed effect and $\varepsilon_{i t v}$ is an error term.

\footnotetext{
${ }^{5}$ Moreover, in 55 percent of the cases, calorie intake would exceed 80 percent of the recommended norm which is the level of consumption used by previous studies to define food insecurity in the region (Reardon and Matlon, 1989).

${ }^{6} \mathrm{An}$ important issue is how these costs are redistributed within the household. Unfortunately, our data are not well-suited to an examinination of food reallocation within the household.
} 
Estimates of regression (1) are reported in table 4. The table shows separate results for poor and wealthier households, where a household is defined as wealthy if it posses animal traction at the start of the survey. Beneath each column, we report the $F$ statistic for the joint significance test of the instruments. The null hypothesis that all instruments are jointly non-significant is rejected at the one percent level across all specifications (the $F$ statistic ranges from 4.67 to 7.91 ). Rainfall affects income through its interactions with land topology and distance from the compound. The income of households with plots on lowland and near the compound is less sensitive to rainfall variations than that of those with plots in upland areas or distant from the compounds. Fafchamps, Udry, and Czukas (1998) and Matlon and Fafchamps (1989) show similar results.

We use regression 1 to assess the variation of income during the survey period. We predict idiosyncratic shocks using the interaction terms $\left(\left(X_{i t v}^{\prime} \otimes F_{v t}\right) \hat{\alpha}_{2}\right)$ and aggregate shocks using the village-year fixed effects $\left(\hat{\gamma}_{t v}\right)$. Table 5 shows the coefficient of variation for these shocks for each village. There is appreciable rainfall-induced idiosyncratic risk in these villages. However, it is apparent that aggregate income volatility is the main source of concern, with a standard deviation about twice of the mean income in most villages.

In summary, we are examining consumption by extremely poor households who were confronted with enormous exogenous income shocks. Yet these households chose to hold onto their main asset (livestock) at the apparent cost of more variation in consumption.

\section{Consumption smoothing}

Limited livestock sales in the face of severe adverse income shocks could simply reflect the availability of alternative mechanisms for smoothing consumption. We first examine self-insurance, and then risk sharing at the village level.

\subsection{Self-insurance}

In this section, we examine the degree of consumption smoothing over time with respect to income shocks. This is primarily an empirical exercise, although its interpretation can best be viewed 
within the simple life-cycle consumption smoothing paradigm that we develop below. Consider a world with missing insurance markets but with well functioning credit markets. In particular households can borrow or save at the market interest rate. We first consider the simple PIH model, and then we test a buffer stock model more consistent with precautionary saving.

\subsubsection{The PIH model}

Each household $i$ maximizes an intertemporal expected utility, with an instantaneous utility $u$ defined over the consumption of a single aggregate good $c_{i}$. Households are supposed to be risk averse, with a planning horizon $T$. Each period, household $i$ earns a risky income $y_{i}$, and has access to a risk-free asset $A_{i}$. With time discount rate $\beta$ and interest rate $r$, household $i^{\prime} s$ economic program at period $\tau$ can be written as follows:

$$
\operatorname{Max}_{c_{i \tau}} u\left(c_{i \tau}\right)+\beta^{t-\tau} E_{t=\tau}\left[\sum_{t=\tau+1}^{T} u\left(c_{i t}\right)\right]
$$

subject to the budget constraint:

$$
A_{i t+1}=(1+r) A_{i t}+y_{i t}-c_{i t}
$$

With $T$ large enough and $A_{i T+1}=0$, then this problem results in the standard permanent income result that the marginal utility of current consumption is equal to the discounted expected marginal utility of future consumption(Deaton, 1992b).

$$
u^{\prime}\left(c_{i t}\right)=\beta(1+r) E u^{\prime}\left(c_{i t+1}\right)
$$

If we assume that preferences are quadratic, separable across periods, and time invariant, and that the rate of time preference is constant and equal to the interest rate, then the changes in consumption from period to period can be expressed as a function of unexpected changes in permanent income. An empirical formulation would suggest that only shocks to permanent income would change optimal the consumption plan, and transitory shocks are smoothed (Deaton, 1992b) 


$$
c_{i v t}=\gamma_{0}+\gamma_{1} y_{i v t}^{P}+\gamma_{2} y_{i v t}^{T}+\gamma_{3} y_{i v t}^{U}+\gamma z_{i t}+d_{i}+v_{i v t}
$$

Where $y^{P}$ is permanent income, $y^{T}$ is transitory income, $y^{U}$ is residual income, $d_{i}$ is a household fixed effect, and all other variables are as defined before. Permanent and transitory income are defined following (Paxson, 1992). To do so, we estimate regression 1, but omitting $\gamma_{t v}$ and including a constant in $X_{i t v}$. Thus the village-level rainfall shock now enters 1 directly as well as through interactions with household land characteristics. Transitory income is defined as $\left(\tilde{X}_{i t v}^{\prime} \otimes F_{v t}\right) \hat{\alpha}_{2}$, where $\tilde{X}_{i t v}=\left[\begin{array}{ll}1 & X_{i t v}\end{array}\right]$, permanent income is defined as $z_{i t v} \hat{\alpha}_{1}$, any $y^{U}$ is the residual income.

The PIH implies that $\gamma_{1}$ is unity and $\gamma_{2}$ is zero. Finally, to allow for systematic inter-household differences in the extent of consumption smoothing, we stratify our sample by household wealth, as in Table 4.

Estimates of this regression are shown in table 6. In the first column we assume identical consumption responses to income shocks across all households, and in the second column we allow parameters to vary by wealth groups. There is no evidence that consumption does responds to changes in permanent income. This is not particularly surprising in this household fixed-effect regression, because our measure of changes in permanent income is unlikely to be particularly informative. It is based on changes in the demographic structure of the household over time, which is likely to be largely predictable. The results that follow are robust to the exclusion of $y^{P}$ from these equations, as can be seen in column 3 .

In contrast, about 54 percent of changes in transitory income are passed onto consumption. There is no significant difference in the responsiveness of consumption to transitory income for poor and wealthier households. In columns 4 and 5, we restrict attention to the periods for which we have direct consumption measures, and do not rely on the flow accounting method of inferring consumption. The responsiveness of consumption to transitory income is quite similar for this subperiod. Overall, the evidence indicates that changes in consumption track those in transitory income, which suggests that households are unable to smooth consumption in the face of year-toyear fluctuations in income. Such a pattern is incompatible with the standard permanent income 
model.

The estimates presented in table 6 may be inconsistent because the model does not account properly for family labor. Crop income is measured as farm gross output minus hired input costs and minus the value of household labor used on the farm (imputed at period-village specific wages). In an agricultural economy characterized by well-developed labor markets and perfect substitutability between family and hired labor, this would be an appropriate procedure (Rosenzweig and Wolpin, 2000). However, hired labor is virtually absent our context (Fafchamps 1993). Overall, only $12 \%$ of labor used on farms in these villages is hired; most of that is used for harvesting cotton in only two of the villages. Apart from the cotton harvest, over 95\% of the labor used on household farms is supplied by the households.

Therefore, it is more appropriate to examine the consequences for consumption smoothing of absent labor markets. Per-period preferences are now

$$
u\left(c_{i t}, l_{i t}\right)
$$

where $l_{t}$ is leisure in period $t . u(c, l)$ is assumed to be concave and increasing in $c$ and $l$. We also make the substantive assumption that $\frac{\partial^{2} u}{\partial c \partial l} \leq 0$. This is a simple way of thinking about nutritionproductivity links. When households are working particularly hard ( $l$ is low), the marginal utility of consumption is high. The budget constraint is modified from (3) to

$$
A_{i t+1}=(1+r) A_{i t}+f\left(1-l_{i t}, \varepsilon_{i t}\right)-c_{i t}
$$

where $f(.,$.$) is farm output as a function of household labor input and the transitory random shock$ $\varepsilon_{i t}$. In any period, consumption and labor choices satisfy

$$
\begin{aligned}
u_{c} & =\lambda_{i t} \\
u_{l} & =f_{L} \lambda_{i t} \\
\lambda_{i t} & =E_{t} \beta\left(1+r_{t}\right) \lambda_{i t+1} .
\end{aligned}
$$


Consumption may no longer be unresponsive to transitory shocks. A transitory shock is defined in the context of perfect smoothing as one that does not influence $\lambda_{i t}$. Imposing the assumption that $\frac{\delta \lambda_{i t}}{\delta \varepsilon_{i t}}=0$, equations (8) imply

$$
\frac{d c_{i t}}{d \varepsilon_{i t}}=-\frac{\lambda_{i t} u_{l c} f_{L \varepsilon}}{D_{i t}}
$$

where $D_{i t} \equiv u_{c c} u_{l l}+\lambda_{i t} u_{c c} f_{L L}-u_{l c}^{2}>0$. Even if there is perfect smoothing, consumption changes with transitory shocks depending on the effect of these shocks on the marginal product of labor. $u_{l c}<0$, so consumption increases (decreases) if these transitory shocks increase (decrease) the marginal product of labor. Therefore, we can use our data on labor demand on household plots to examine the null hypothesis of perfect smoothing, even in the absence of complete labor markets.

Our IV estimate of the impact of transitory income shocks on consumption is

$$
\frac{\frac{d c_{i t}}{d \varepsilon_{i t}}}{\frac{d f_{i t}}{d \varepsilon_{i t}}}=\frac{-\frac{\lambda_{i t} u_{l c} f_{L \varepsilon}}{D_{i t}}}{f_{\varepsilon}-f_{L} \frac{\lambda_{i t} f_{L \varepsilon}\left(u_{l l}+\lambda_{i t} f_{L L}\right)}{D_{i t}}} .
$$

where $f_{i t}=f\left(1-l_{i t}, \varepsilon_{i t}\right)$. Similarly, we can examine the impact of the same transitory shocks on farm labor demand $\left(L_{i t} \equiv 1-l_{i t}\right)$. Under the null hypothesis of complete smoothing, the IV estimate of this coefficient is

$$
\frac{\frac{d L_{i t}}{d \varepsilon_{i t}}}{\frac{d f_{i t}}{d \varepsilon_{i t}}}=\frac{-\frac{\lambda_{i t} f_{L \varepsilon}\left(u_{l l}+\lambda_{i t} f_{L L}\right)}{D}}{f_{\varepsilon}-f_{L} \frac{\lambda_{i t} f_{L \varepsilon}\left(u_{l l}+\lambda_{i t} f_{L L}\right)}{D}} .
$$

Without further assumptions, in particular on the sign and magnitude of $f_{L \varepsilon}$, we can not say much about either of these two quantities. However, their ratio is

$$
\frac{\frac{\frac{d c_{i t}}{d \varepsilon_{i t}}}{\frac{d f_{i t}}{d \varepsilon_{i t}}}}{\frac{\frac{d L_{i t}}{d d_{i t}}}{\frac{d f_{i t}}{d \varepsilon_{i t}}}}=\frac{u_{l c}}{\left(u_{l l}+\lambda_{i t} f_{L L}\right)}>0,
$$

and thus they must have the same sign. If households smooth perfectly, consumption and farm labor demand must move in the same direction in response to transitory shocks.

This restriction is strongly rejected in the data. We showed in Table 6 that $\frac{\frac{d c_{i t}}{d \varepsilon_{i t}}}{\frac{d f_{i t}}{d \varepsilon_{i t}}}>0$. In Table 7, we present results from estimating equation (5), with $c$ replaced by $L$. We find that $\frac{\frac{d L_{i t}}{d \varepsilon_{i t}}}{\frac{d f_{i t}}{d \varepsilon_{i t}}}<0$, 
contradicting the null hypothesis that households are able to fully smooth the effect of transitory income shocks. In Column 1 of Table 7, we see that positive transitory shocks to income are strongly associated with declines in labor use on the household farm. A one standard deviation increase in income is associated with decline of about 335 hours of total labor, which is approximately $9 \%$ of total labor use. The decline in labor use is larger for poorer households. The decline in household labor on the farm associated with the same transitory shock is approximately $7 \%$ of total household labor use. This decline is evident for both men and women household members, though not for children. These declines are strongly statistically significant, and of moderate size. ${ }^{7}$

We find that consumption increases in response to transitory income shocks. At the same time, we find labor use on the farm declining in response to the same shocks. This contradicts the null hypothesis of perfect consumption smoothing. It is an unsurprising outcome under conditions of imperfect smoothing. Households with positive $\varepsilon_{i t}$ are temporarily well-off: some of this transitory utility shock is consumed in the form of $c_{i t}$, some the form of increased leisure.

\subsubsection{Asset Stocks and Consumption Smoothing}

We turn now to the mechanisms that might be used to smooth consumption over time. This serves as an important robustness check on the preceding results, because the data are partly independent of the information on consumption we have used to this point. There is no significant use of financial assets in these communities, so the primary assets that could be used to smooth consumption are consumer grain stocks, livestock holdings, consumer durables and tools. Unfortunately, we have no data on the evolution of holdings of consumer durables or tools. We focus our attention, therefore, on the two key assets of grain stocks and livestock.

The net savings functions for grain and livestock have the same form as the consumption function (5) with $c_{i t}$ replaced by $\Delta a_{i t}$, where $a_{i t}$ is holdings of either grain or livestock by household $i$ in year $t$.

Estimates are presented in table 8. Net savings in grain stocks appear to be a relatively important mechanism for smoothing consumption over time, as found by Udry in northern Nigeria. Put

\footnotetext{
${ }^{7}$ In a very different context, Kochar 1999 also finds hours working responds negatively to idiosyncratic income shocks. Much of the response she finds works through the off-household farm labor market.
} 
a different way, we found in the previous section that there is very little evidence of consumption smoothing. What smoothing there is appears to be effected though variations in grain holdings. The results indicate a positive response of grain saving to both transitory income (.28) and permanent income (.33). This, however, appears to be the case only for relatively wealthy households (column 2). We have already noted that Fafchamps, Udry, and Czukas (1998) find very little responsiveness of net livestock sales to income fluctuations driven by rainfall shocks in these data. We reconfirm this finding in columns 3 and 4 of table 8 .

A source of concern with these results is uncertainty regarding the extent to which livestock price dynamics affect offtake decisions. Are households not selling livestock during this drought because current prices are low? If current prices are low, so that expected returns to holding livestock are temporarily high, livestock sales may be lower than what would be expected in the absence of price dynamics correlated with shocks. We temporarily defer this question, because it is best addressed in the context of an examination of within-village dynamics of livestock holdings, which is discussed in section 3.2 .

\subsubsection{Buffer stocks: Liquidity Constraints and the Precautionary Motive}

If farmers in a risky environment face liquidity constraints, or if they have a preference-based precautionary motive for saving (or both), then the strict restrictions of the PIH no longer hold (Banks, Blundell, and Brugiavini, 2001; Browning and Lusardi, 1996; Carroll, 1997; Carroll and Kimball, 2001; Deaton, 1991, 1992a; Zeldes, 1989). In these cases, farm households will not fully smooth transitory shocks. Instead, they may permit consumption to drop in the face of transitory shocks in order to preserve their buffer stocks against the possibility of future shocks. There is a very close connection between the precautionary savings motive and liquidity constraints. Zeldes (1989) shows that even if a household has no inherent precautionary demand for savings (because preferences are quadratic), liquidity constraints induce precautionary savings. An adverse income shock has a particularly negative impact on a household that faces a binding liquidity constraint, because the shock cannot be spread over time. The household engages in precautionary savings even when the liquidity constraint is not yet binding in order to reduce the chances of it binding in the 
future. Carroll and Kimball (2001) show that for quite general preferences the existence of liquidity constraints increases the demand for precautionary savings when asset holdings fall near the point at which constraints start to bind. Carroll and Kimball conclude that "the effects of precautionary saving and liquidity constraints are very similar, because both spring from the concavity of the consumption function" (p. 38). In either case, we would observe current consumption being especially low for those households that anticipate higher variance in consumption in the future.

Almost none of the now-substantial literature on buffer stock savings addresses the issues associated with nonseparabilities between consumption and labor supply (Browning and Meghir, 1991). There is a significant amount of work that examines intertemporal labor supply in non-stochastic environments (following Heckman, 1974). Research on joint labor supply and savings choices in risky environments with liquidity constraints or a precautionary motive is much less well-established (see Blundell, Magnac, and Meghir, 1997; Low, 1999; Rust, Buchinsky, and Benitez-Silva, 2003, for a sampling of this literature). There is no work to date that addresses the determinants of buffer stock savings in a context of nonseparabilities between consumption and leisure with absent labor markets and home production. It is clear that a full treatment would require explicit solution of the stochastic dynamic program facing these households. This extension is beyond the scope of the current paper. Instead, we note that the statistically-significant labor supply responses to transitory shocks revealed in Table 7 are relatively small. For the purposes of this first examination of buffer stock saving, we treat labor supply as inelastic.

We examine the possibility that there is important precautionary saving by adopting the method of Pistaferri (2001). He argues that observation of subjective expectations of future income variance provides a powerful test of this motive. Campbell's (1987) famous rainy day equation shows that under the PIH, saving depends on expected future changes in income. Does current savings depend, in addition, on higher moments of distribution of future income shocks? Therefore, we estimate

$$
s_{i v t}=\gamma_{1} y_{i v t}^{P}+\gamma_{2} y_{i v t}^{T}+\gamma_{3} y_{i v t}^{U}+\gamma_{4} \operatorname{var}\left(y_{i v t+1}^{T}\right)+\gamma z_{v i t}+\gamma_{v}+\mu_{t} .
$$

We assume that households have rational expectations concerning the distribution of income shocks 
due to rainfall that they can expect. Therefore, we estimate $\widehat{\operatorname{var}}\left(y_{i v t+1}^{T}\right)$ with the time series of rainfall variation, interacted with household land characteristics weighted by the estimates from equation (1). To be more specific, we proceed by re-estimating a version of regression (1) as follows:

$$
y_{i t v}=\alpha_{1} z_{i t v}+\alpha_{2} X_{i t v} \otimes F_{v t}+\alpha_{3} \gamma_{v} \otimes F_{v t}+\gamma_{i}+\varepsilon_{i t v}
$$

We then use our historical rainfall data to recover the variance of rainfall-induced income shocks for each household, assuming that the average characteristics of the households' cultivated land over the five years approximates the total land endowment for each household. ${ }^{8}$

Table 9 summarizes our estimation results. In column (1), we see that conditional on current income shocks, households that have land characteristics that are associated with higher income variance save significantly more. A household with a one standard deviation higher expected future income variance saves CFA 5744 more (per adult equivalent). This is a moderately large effect on consumption and saving: the standard deviation of consumption is approximately CFA 13,000. As can be seen in column (2), there is no apparent difference in the absolute magnitude of the savings response of poor and rich households to expected future income shocks; hence, the responsiveness as a proportion of current consumption or assets is higher for poor households.

In the absence of time-varying measures of future income risk for our households, it is not possible for us to address the main empirical worry associated with this procedure, which is that we are assuming that landholdings are exogenous to other household characteristics, and in particular that they are uncorrelated with preferences over savings. It is of course possible that more risk averse households, or households that face more strict liquidity constraints, adjust their landholdings to reduce the volatility of income shocks. This possibility, along with the fact that we have not appropriately addressed non-separabilities between consumption and leisure in this context of very imperfect labor markets, implies that these results should be understood as preliminary rather than definitive.

\footnotetext{
${ }^{8}$ So $\widehat{\operatorname{var}}\left(y_{i v t+1}^{T}\right) \equiv \operatorname{var}\left(\hat{\alpha}_{2} \bar{X}_{i v} \otimes F_{v t}+\hat{\alpha}_{3} \hat{\gamma}_{v} \otimes F_{v t}\right)$, where the var is taken over the historical period for which we have rainfall data, and $\bar{X}_{i v}$ are the average land characteristics of household $i$ over our 5 years of survey data.
} 


\subsection{Risk sharing}

We turn now to an examination of the extent of risk pooling within these villages. Table 5 shows that in the context of the enormous aggregate income shocks associated with the drought period there is also significant idiosyncratic variation in income. While informal local risk sharing arrangements can do little to help households deal with the aggregate effects of the drought, they might permit households to efficiently pool the idiosyncratic variation within villages. We begin by considering the canonical model of fully efficient risk pooling within the village. The central implication of this model is that changes in individual consumption depend only on aggregate consumption, and are independent of a households' own shocks conditional on aggregate consumption.

We use a familiar specification to test the null hypothesis of complete risk pooling within villages (see Deaton (1990) and Ravallion and Chaudhuri (1997), for example). If preferences are separable between consumption and leisure, and are additively separable across time and states, then consumption growth depends on aggregate resources and not on changes in own resources. Empirically, changes in individual consumption over time should be uncorrelated with changes in individual income conditional on the resources of the reference group:

$$
c_{i t v}=\beta_{1}+\beta_{2} y_{i t v}+\beta_{3} z_{i t v}++\gamma_{i}+\gamma_{t v}+\varepsilon_{i t v}
$$

Where $c$ is consumption, $y$ is income, $\gamma_{t v}$ is a village $\times$ year fixed effect, $\gamma_{i}$ is a household fixed effect, and $z$ is household demographics. Complete risk pooling implies $\beta_{2}=0$. We experiment with variants of equations (15), namely by instrumenting for income, and by accounting for potential endogeneity of the household composition. The instruments for income are described in 2.2 , where we also present the first stage results.

Table 10 sets out estimation results of regression 15. OLS estimates are presented in columns (1) and (2), and IV estimates in columns (3) to (4). The last column shows results from the Arellano-Bond (AB) estimator, which treats both income and household size as endogenous and uses lagged variables as instruments (Arellano and Bond, 1991; Jalan and Ravallion, 1999). All regressions include village-year fixed effects to control for covariate shocks. In columns (2) and (4), 
we allow the degree of consumption smoothing to differ between rich and poor households.

Across all specifications, the income coefficients are positive and different from zero at any conventional level. Therefore, the null hypothesis of perfect insurance against idiosyncratic income risk is rejected.

The point estimates suggest that on average the effect of idiosyncratic income shocks on consumption ranges from 37 percent to 51 percent with OLS estimates, and from 31 percent to 44 percent when we instrument for income. The estimated income coefficient using the AB estimator is 43 percent, implying that the lack of risk sharing is robust to this alternative identification strategy for the income shocks.

We focus our interpretation on the IV results for two reasons. First, there is substantial evidence from other poor agrarian economies of nutrition-productivity effects that imply joint causation between income and consumption (Strauss, 1986; Strauss and Thomas, 1995). Second, it is plausible that there are measurement and/or imputation errors in the income variable. Measurement errors per se would tend to induce an attenuation bias that biases coefficients towards zero (Deaton, 1997; Ravallion and Chaudhuri, 1997). In this case, the OLS estimates provide a lower bound for the true parameters. However, imputation errors in the construction of both the consumption and the income variables may bias the income coefficients upwards (Deaton, 1997; Ravallion and Chaudhuri, 1997) ${ }^{9}$. For positive coefficients, this bias is in opposite direction of the standard downward attenuation bias due to measurement errors, so that the net effect cannot be signed a priori.

We test whether the extent of risk sharing differs between rich and poor households. The point estimates imply a stronger sensitivity of consumption to idiosyncratic shocks for poor households, but in our IV specification we cannot reject the hypothesis that the responsiveness is the same. ${ }^{10}$ Thus, we cannot claim that the consumption of wealthier households is more protected against idiosyncratic income shocks than the consumption of poorer households, a finding which contrasts the results of Jalan and Ravallion (1999) in rural China. Overall, it is clear that a large proportion

\footnotetext{
${ }^{9}$ This is critical in our context where most of the data on consumption is derived from an accounting flow.

${ }^{10}$ Note that the difference is statistically significant in column (2), i.e. using measured income. However, we have already argued that income may be endogenous.
} 
of idiosyncratic variation in income is uninsured for households at all levels of wealth.

In section 2 we saw that conventional treatments of the permanent income hypothesis can be misleading in a context in which preferences are not separable between leisure and consumption and labor markets are imperfect or absent. The same is true in the context of tests for efficient consumption insurance. Suppose as we did in section 2 that nutrition-productivity connections imply that the marginal utility of consumption is increasing in labor supply $\left(u_{l c}<0\right)$, and that production is based on household labor, due to absent labor markets. The implication (in a derivation almost identical to that of equation (12), so not repeated here) is that in an efficient allocation with full insurance, idiosyncratic consumption must move in the same direction as idiosyncratic labor use. The intuition is that conditional on aggregate labor and consumption, if labor supply increases for household $h$ due to a change in the marginal product of labor on $h$ 's farm, then $h$ 's consumption must also increase to fully pool risk.

We can test this implication of full insurance by estimating an equation similar to (15), but with $c$ replaced by $L-$ labor use on the farm. The results are presented in columns (6) and (7) of Table 10. We see that labor use is declining in farm output, conditional on household and villageyear fixed effects. Households with positive idiosyncratic shocks consume more, and work less. This contradicts the null hypothesis of complete insurance, even with non-separabilities between consumption and leisure and absent labor markets.

In regression (15), all aggregate shocks are absorbed in the village-time fixed effects, making the test agnostic on households' ability to cope with aggregate shocks. Given the timing of the survey, a period characterized by severe drought, it may be informative to examine households ability to cope with aggregate shocks.

One option to examine the exposure to aggregate risk is simply to exclude the village-time fixed effects, which summarize the covariate shocks, from regression (15), and estimate the following regression:

$$
c_{i t v}=\beta_{1}+\tilde{\beta}_{2} y_{i t v}+\beta_{3} z_{i t v}+\gamma_{i}+\varepsilon_{i t v}
$$


The coefficient $\tilde{\beta}_{2}$ provides an estimate of consumption variability inclusive of both idiosyncratic and aggregate shocks. If aggregate shocks are important and there is substantial risk sharing, then $\tilde{\beta}_{2}>\beta_{2}$, and the difference $\delta=\tilde{\beta}_{2}-\beta_{2}$ summarizes the role of risk sharing (Deaton, 1990; Jalan and Ravallion, 1999).

Table 11 presents the estimation results, with income instrumented as discussed before. The implied $\delta^{\prime} s$ are presented in the last row. From the estimates, it is apparent that risk sharing is not central to consumption smoothing. This means that households relied almost exclusively on self-insurance to smooth consumption during the survey period. This finding should be put in perspective with the timing of the survey discussed in section (2). In particular one might think that the persistence of negative aggregate shocks which resulted from a succession of drought years may have undermined existing social arrangements used to shared risk. Anecdotal evidence in Northern Burkina, where villagers have reported the break-ups of extended households and traditional reciprocity networks in the aftermath of the drought of the 1970's (Marchal, 1974), seems to support this hypothesis.

\subsubsection{Mechanisms of risk sharing}

To complement our previous tests on consumption smoothing, we look directly at mechanisms which households may use to cope with income risk. We first examine transfers, which could be an important mechanism for informal risk sharing. We estimate transfers response to income shocks using the following regression:

$$
T_{i v t}=\beta_{1}+\beta_{2} y_{i t v}+\beta_{3} z_{i t v}+\gamma_{t v}+\gamma_{i}+\varepsilon_{i t v},
$$

where $T$ is net transfers defined as the difference between transfers received and transfers given. If complete risk pooling is implemented through transfers, we would expect $\beta_{2}$ to be -1 . Conditional on aggregate consumption $\left(\gamma_{t v}\right)$, a decrease of CFA 1 in income would be met with an increase of CFA 1 in transfers, and vice-versa. Estimates of (17) are reported in table 12. The estimates imply that income risk has almost no effect on net transfers (the estimated coefficient is small in 
magnitude and not statistically significant). Thus, overall gifts giving within the village were not used to pool risk. This result is consistent with the evidence presented in table 11. Moreover, the descriptive statistics (table 3) indicated that transfers were too small to play any significant role in consumption smoothing.

To corroborate our finding of minimal risk sharing, we test how asset holdings (grain storage and livestock) respond to idiosyncratic, transitory shocks. In table 13 we test the extent to which self-insurance mechanisms (grain storage and livestock sales) respond to idiosyncratic shocks, by estimating versions of regression 17 where the dependent variable is grain storage (columns 1 and 2) and livestock sales (columns 3 and 4), respectively. On average 41 percent of idiosyncratic shocks are passed onto grain storage (column 1) and only about 2 percent are passed onto livestock sales.

The most important reason for examining the responsiveness of livestock sales to idiosyncratic shocks is that it sheds light on the hypothesis that the reluctance of households to smooth consumption shocks with livestock transactions is related to the dynamics of livestock prices in drought situations. It is argued that livestock mortality during drought periods and reduced pressure on common grazing land afterwards lead to higher prices in subsequent periods because of local supply shortages (Fafchamps, Udry, and Czukas, 1998) ${ }^{11}$. Therefore current low rainfall may provide some incentives to hold onto livestock, and observed offtake will be lower than that would have prevailed in the absence of price dynamics. However, we see from columns (3) and (4) that within villages, households subject to transitory idiosyncratic shocks are no more likely to sell livestock than other households. Because these are conditional on village-year fixed effects, one cannot attribute the lack of livestock adjustment to shocks to differences in the expected future path of future livestock prices.

\section{Income shocks and herd management}

A final prominent hypothesis for the apparent reluctance of many households to sell livestock to smooth consumption is based on livestock production technology. We start from the observation

\footnotetext{
${ }^{11}$ See Sheets and Morris (1973) for a descriptive account of herd recovery after drought years in the Sahel in the mid-1970's.
} 
that in the absence of any consumption-smoothing motive (because there is no risk, or because there are efficient insurance markets) optimal herd management still implies periodic sales. This type of offtake, however, is governed only by profit objectives ${ }^{12}$. There may be a tension between these objectives and any desire of households to smooth consumption, reducing the usefulness of animal stocks for dealing with transitory risk.

To motivate our empirical model, consider the standard finite-horizon household model under complete markets. Each household $(h)$ maximizes its utility, which is defined over state contingent consumption

$$
u_{h}\left(c_{h s t}\right)
$$

The household's budget constraint is

$$
\sum_{s t} q_{s t} c_{h s t} \leq \sum_{s t}\left[\pi_{h s t}+q_{s t} n_{h s t}+w_{s t}\left(E_{h s t}-l_{s t}\left(N_{h s t}\right)\right)\right]
$$

where $p_{s t}$ is the price of consumption, $\pi_{h s t}$ is $h$ 's farm profit, and $E_{h s t}$ is the endowment of labor of $h$ in state $s$ in period $t$. $N_{h s t}$ is the vector of animals of different ages held by household $h$ in state $s$ of period $t$. We can think of it as having $A$ elements, each describing how many cattle of age $a$ are held by the household at a particular moment; more generally it will record gender- and agespecific quantities held of all different types of livestock. $l_{s t}$ is the state- and period-specific labor requirement of holding that vector of animals, which might depend on local pasture conditions. $n_{h s t}$ is the vector of net sales of livestock of different ages by $h$, and $q_{s t}$ are the prices at which those sales are realized. Livestock holdings evolve according to

$$
N_{h s^{\prime} t+1}=G_{s t}\left(N_{h s t}\right)-n_{h s t}
$$

where $G_{s t}$ describes the births, deaths, and aging of livestock from state $s$ of $t$ to $s^{\prime}$ of $t+1{ }^{13}$ Completing the model with the obvious non-negativity conditions and definition of farm profit, it

\footnotetext{
${ }^{12}$ Whether profit is defined in monetary or non-monetary (i.e. livestock may be also used to signal social prestige) would not affect the argument.

${ }^{13}$ Without loss of generality, we have defined states such that conditional on state $s$ of $t$ these transitions are the same into any state $s^{\prime}$ of $t+1$.
} 
is immediately apparent that the usual separability holds between production and consumption decisions.

It follows that the household problem is akin to maximizing profit, and then using the optimal profit in the budget constraint of the consumption problem. Under the complete market assumption, the household chooses an optimal sequence $\left\{n_{h s t}^{*}\right\}$ that maximizes profit derived from livestock. This sequence of net sales is independent of household preferences, and uninfluenced by any desire to cope with risk: $\left\{n_{h s t}^{*}\right\}$ is the same regardless of the degree of risk aversion in $u_{h}$.

We can say a bit more from the separable structure of the household's problem. The price sequences $p_{s t}, q_{s t}$ and $w_{s t}$, and the production functions $l_{s t}($.$) and G_{s t}($.$) are all community specific.$ Conditional on the aggregate state at time $t$ in a given community, they do not depend upon the idiosyncratic income shock of household $h$. As with the rest of this argument, this depends crucially on the completeness of factor markets in the community. It requires, for example, that pasture is open with a well-defined price (which we've embedded in $w_{s t} l_{s t}($.$) above) to all in the$ community. If this was not so, then rainfall shocks on household land might influence $\left\{n_{h s t}^{*}\right\}$. This is just a particular example of the common and correct observation that separation of production and consumption decisions requires smoothly-working factor markets.

We now examine the null hypothesis that the sales of animals of particular ages are uninfluenced by the realization of idiosyncratic income shocks. We have data on the age, the type and the sex of each animal sold by sample households. We pool all animals (cattle, goat, and sheep) and calculate for each animal sold by household $h$ in period $t$ its standardized age $\left(s_{i h t}\right)$ based on the average life expectancy of each type of animal. We estimate

$$
s_{i h t}=\tau_{1} y_{h t}+\tau_{2} z_{h t}+m_{l s t v}+\mu_{i h t}
$$

where $y_{h t}$ is crop income, $z$ is household composition capturing labor costs and $m_{l s t v}$ is a livestock, sex, village, year dummy variable which captures local market and livestock production conditions. Note that these fixed effects will capture the effects of both current and expected future prices.

Optimal herd management implies that households choose the age at which each animal is 
sold based only on the local market and physical production conditions $\left(m_{l s t v}\right)$, which together determine the net profit per animal. The null hypothesis is that $\tau_{1}=0$. A positive $\tau_{1}$ indicates that households who experience negative income shocks sell younger animals. That is, negative income shocks force household to deviate from the optimal herd management path. In all cases, $y_{h t}$ is treated as endogenous and instrumented with interactions of rainfall shocks with household farmland characteristics, as in earlier tables. Note that the inclusion of $m_{l s t v}$ implies that our test can only reveal deviations from the null hypothesis caused by idiosyncratic variations in crop income; aggregate movements are captured in the fixed effect.

In table 14, we report estimates of equation (18) with and without household fixed effects. We find no evidence of any sensitivity of livestock ages to income shocks in any of these specifications.

The most direct interpretation of this failure to reject the null hypothesis is that the complete markets assumption is correct. This is implausible, given the earlier results of the paper. An alternative interpretation is that the cost of deviating from the optimal sequence of livestock sales is sufficiently high that households subject to adverse shocks are not willing to do so. We can only examine the responsiveness of livestock ages at sale to idiosyncratic income shocks (because of the likelihood that local market and production conditions are related to the aggregate shocks). These idiosyncratic shocks may be too small to induce noticeable changes in the ages of livestock at sale.

\section{Conclusion}

This paper has investigated patterns of consumption smoothing by rural households in the WASAT. These households experienced extreme aggregate income shocks during a period of severe drought. These aggregate shocks were accompanied by substantial idiosyncratic income variation. However, we found little evidence of consumption either over time or across households within villages. The small amount of consumption smoothing that we found was effected largely through the accumulation and decumulation of stocks of grain.

The evidence uncovered suggests that households intentionally destabilized consumption in order to conserve livestock through the drought period, contradicting simple optimal saving theories. 
Household behavior appears to be more consistent with a buffer stock model than conventional risk sharing or PIH models. This conclusion is based on two complementary findings from our reduced form analysis. First, poor households already close to subsistence levels who were subjected to large income shocks endured drops in consumption in order to hold onto their remaining livestock. Second, households whose land characteristics implied higher future income variability saved more, conditional on current income shocks.

The next step in this research agenda, therefore, is to develop a more structural model that accounts for the key features that seem to be driving dynamic decisions regarding consumption and saving in this context. We believe that there are three such features. First, households are faced with potentially binding liquidity constraints, given current livestock holdings and the stochastic process that governs income in the area. Second, labor markets are virtually absent and there are important non-separabilities between the consumption of leisure and food. Finally, livestock sales and purchases involve significant transaction costs, and there are potentially important herd management considerations that influence the decision to modify the portfolio of livestock held by a particular household. We expect that a buffer stock model in the line of Deaton (1991) and Carroll (1997), extended to account for constraints raising from herd management considerations and nutrition-productivity connections may provide a more complete characterization of the data. 


\section{References}

Alderman, H., And C. H. Paxson (1994): "Do the Poor Insure? A Synthesis of the Literature on Risk and Consumption in Developing Countries," in Economic in a Changing World, ed. by E. L. Bacha, vol. Development, Trade and the Environment, chap. 3, pp. 48-78. Macillan, London.

Arellano, M., And S. Bond (1991): "Some Tests of Specification for Panel Data: Monte-Carlo Evidence and an Application to Employment Equation," Review of Economic Studies, 58, 277298.

Attanasio, O., and M. Szekely (2004): "Wage Shocks and Consumption Variability in Mexico during the 1990s," Journal of Development Economics, 73(1), 1-25.

Banks, J., R. Blundell, and A. Brugiavini (2001): "Risk Pooling, Precautionary Saving adnd Consumption Growth," Review of Economic Studies, 68(4), 757-779.

Barbe, L., T. Lebel, and D. Tapsoba (2002): "Rainfall Variablity in West Africa During the Years 1950-90," Journal of Climate, 15(00), 187-202.

Bardhan, P., And C. Udry (1999): Development Microeconomics. Oxford University Press, Oxford, New York.

Blundell, R., T. Magnac, and C. Meghir (1997): "Savings and Labor-Market Transitions," Journal of Business and Economic Statistics, 15(2), 153-164.

Browning, M., And A. Lusardi (1996): "Household Saving: Micro Theories and Micro Facts," Journal of Economic Literature, 34, 1797-1855.

Browning, M., And C. Meghir (1991): "The Effects of Male and Female Labor Supply on Commodity Demands," Econometrica, 59(4), 925-951.

Carroll, C. D. (1997): "Buffer-stock saving and the life cycle/permanent income hypothesis," Quarterly Journal of Economics, 107, 1-55. 
Carroll, C. D., and M. S. Kimball (2001): "Liquidity Constraints and Precautionary Saving," Working Paper 2001, Department of Economics, The Johns Hopkins University, Baltimore, MD. Deaton, A. (1990): "On Risk, Insurance and Intra-Village Consumption Smoothing," Research Program in Development Studies, Princetone University, N.J.

_ (1991): "Saving and Liquidity Constraints," Econometrica, 59.

(1992a): "Household Saving in LDCs: Credit, Markets, Insurance and Welfare," Scandinavian Journal of Economics, 94(2), 253-273.

(1992b): Understanding Consumption. Oxford University Press, New York.

- (1997): The Analysis of Household Surveys. The World Bank, Baltimore: John Hopkins.

Dercon, S. (2004): Insurance Against Poverty, WIDER Studies in Development Economics. Oxford University Press, Oxford, U.K.

Fafchamps, M., And S. Lund (2003): "Risk-Sharing Networks in Rural Philippines," Journal of Development Economics, 71(2), 261-287.

Fafchamps, M., C. Udry, and K. Czukas (1998): "Drought and Saving in West Africa: Are Livestock a Buffer Stock?," Journal of Development Economics, 55(2), 273-305.

Famine Early Warning System (1999): "FEWS Current Vulnerability Assessment Guidance Manual: Introduction to Current Vulnerability Guidelines," Technical report, USAID FEWS Project.

FAO-WHO-UNU (1985): "Energy and Protein Requirments," Expert consulations, Food and Agriculture Organization-World Health Organization-United Nation University, WHO: Geneva. Heckman, J. (1974): "Shadow Prices, Market Wages and Labor Supply," Econometrica, 42(4), $679-694$.

Hoogeveen, H. (2002): "Evidence on Informal Insurance in Rural Zimbabwe," Journal of African Economies, 11(2), 249-278. 
Jalan, J., And M. Ravallion (1999): "Are the Poor Less Well Insured? Evidence on Vulnerability to Income Risk in Rural China," Journal of Development Economics, 58(1), 61-81.

Kinsey, B., K. Burger, and J. W. Gunning (1998): "Coping with Drought in Zimbabwe: Survey Evidence on Responses of Rural Households to Risk," World Development, 26(1), 89110.

Low, H. (1999): "Self-insurance and Unemployment Benefit in a Life-cycle Model of Labour Supply and savings," Institute for Fiscal Studies Working Paper, 52.

Marchal, J. Y. (1974): "Recolte et Disettes en Zone Nord-Soudanienne: Chronique des Saisons Agricoles au Yatenga (Haute Volta) de 1907 a 1973," ORSTOM, Ouagadougou, Burkina Faso.

Matlon, P. (1988): "Burkina Faso Farm Level Studies: Survey Methods and Data Files," Economics group, VLS and miscellaneous papers series, ICRISAT, Hyderabad, India.

Matlon, P., And M. Fafchamps (1989): "Crop Budgets in Three Agro-Climatic Zones of Burkina Faso," ICRISAT Progress Report. Hyderabad, India.

Nicholson, S., And J. P. Grist (2001): "A Conceptual Model for Understanding Rainfall Variability in the West African Sahel on Interannual and Interdecadal Timescales," International Journal of Climatology, 21(00), 1733-1757.

Paxson, C. H. (1992): "Using Weather Variability to Estimate the Response of Saving to Transitory Income in Thailand," American Economic Review, 82(1), 15-33.

Pistaferri, L. (2001): "Superior Information, Income Shocks, and the Permanent Income Hypothesis," Review of Economics and Statistics, 83(3), 465-476.

Ravallion, M., and S. Chaudhuri (1997): "Risk and Insurance in Village India: Comment," Econometrica, 65(1), 171-84.

Reardon, T., C. Delgado, and P. Matlon (1992): "Determinants and Effets of Income Diversification among Farm Households in Burkina Faso," Journal of Development Studies, 28(2), 264-296. 
Reardon, T., And P. Matlon (1989): "Seasonal Food Insecurity and Vulnerability in DroughtAffected Regions of Burkina Faso," in Seasonal Variability in Third World Agriculture: The Consequences for Food Security, ed. by D. E. Sahn, chap. 8, pp. 118-136. The International Food Policy Research Institute, Washington D. C., USA.

Rosenzweig, M. R., And K. I. Wolpin (1993): "Credit Market Constraints, Consumption Smoothing, and the Accumulation of Durable Production Assets in Low-Income countries: Investments in Bullocks in India," Journal of Political Economy, 101(2), 223-44.

_ (2000): "Natural Natural Experiments in Economics," Journal of Economics Litterature, $38(4), 827-874$.

Rust, J., M. Buchinsky, and H. Benitez-Silva (2003): "Dynamic Structural Models of Retierement and Disability," Working Paper, SUNY-Stony Brook, Department of Economics.

Sheets, H., And R. Morris (1973): "Disaster in the Desert," in The Politics of Natural Disaster: The Case of the Sahel Drought, ed. by M. H. Glantz, chap. 2. Praeger Publishers, New York.

Strauss, J. (1986): "Does Better Nutrition Raise Farm Productivity?," Journal of Political Economy, 94(2), 297-320.

Strauss, J., and D. Thomas (1995): "Human Resources: Empirical Modeling of Household and Family Decisions," in Handbook of Development Economics, ed. by J. Behrman, and T. N. Srinivasan, vol. 3A, pp. 1883-2023. Elsevier Science, North Holland.

Tapsoba, D., M. Hache, L. L. Perreault, and B. Bobee (2004): "Bayesian Rainfall Variability Analysis in West Africa Along Cross Sections in Space-Time Grid Boxes," Journal of Climate, 17(1), 1069-1082.

Townsend, R. M. (1994): "Risk and Insurance in Village India," Econometrica, 62(3), 539-91.

Zeldes, S. P. (1989): "Consumption and Liquidity COnstraints: An Empirical Investigation," Journal of Political Economy, 97, 275-298. 
Table 1: Village rainfall data

\begin{tabular}{lrrrrr}
\hline \hline Villages & 1981 & 1982 & 1983 & 1984 & 1985 \\
Sahelian region & & & & & \\
Woure & 362 & 324 & 441 & 302 & 201 \\
& 0.75 & 0.68 & 0.92 & 0.63 & 0.42 \\
Silgey & 444 & 314 & 425 & 295 & 234 \\
& 0.93 & 0.65 & 0.89 & 0.62 & 0.49 \\
Sudanian region & & & & & \\
Kolbila & 646 & 555 & 573 & 423 & 477 \\
& 0.89 & 0.76 & 0.79 & 0.58 & 0.66 \\
Ouonon & 504 & 525 & 401 & 533 & 469 \\
& 0.7 & 0.73 & 0.55 & 0.74 & 0.65 \\
Northern-Guinean region & & & & \\
Koho & 666 & 770 & 725 & 783 & 877 \\
& 0.7 & 0.81 & 0.76 & 0.82 & 0.92 \\
Sayero & 865 & 561 & 634 & 676 & 664 \\
& 0.9 & 0.59 & 0.67 & 0.71 & 0.7 \\
\hline \hline
\end{tabular}

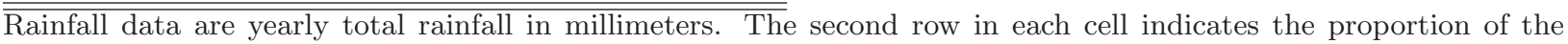
long-run regional average rainfall received in a given year.

Source: Fafchamps, Udry, and Czukas (1998, p.284) 
Table 2: Summary statistics

\begin{tabular}{|c|c|c|c|c|c|c|}
\hline & $(1)$ & $(2)$ & $(3)$ & $(4)$ & $(5)$ & (6) \\
\hline & \multicolumn{2}{|c|}{ Sahel } & \multicolumn{2}{|c|}{ Soudanian } & \multicolumn{2}{|c|}{ Northern Guinean } \\
\hline & Woure & Sigley & Kolbila & Ouonon & Koho & Sayero \\
\hline \multirow[t]{2}{*}{ consumption } & 32.98 & 27.57 & 22.82 & 15.78 & 17.92 & 19.42 \\
\hline & $(17.23)$ & $(12.44)$ & $(13.31)$ & $(6.36)$ & $(8.83)$ & $(11.61)$ \\
\hline \multirow[t]{2}{*}{ cropincome } & 21.82 & 18.17 & 20.10 & 15.14 & 21.12 & 27.40 \\
\hline & $(15.84)$ & $(12.10)$ & (12.97) & $(7.39)$ & $(16.40)$ & $(22.99)$ \\
\hline \multirow[t]{2}{*}{ income } & 26.25 & 21.21 & 22.72 & 16.83 & 25.57 & 31.54 \\
\hline & $(17.93)$ & $(16.87)$ & $(12.80)$ & $(8.45)$ & $(17.32)$ & $(24.30)$ \\
\hline \multirow[t]{2}{*}{ Change in consumption } & -6.23 & -4.51 & -1.08 & 2.38 & 2.85 & 0.65 \\
\hline & $(25.67)$ & $(18.38)$ & $(16.81)$ & $(7.54)$ & $(13.61)$ & $(13.53)$ \\
\hline \multirow[t]{2}{*}{ Change in crop income } & -9.50 & -5.84 & -9.23 & 1.95 & 5.50 & 2.35 \\
\hline & $(21.52)$ & $(16.25)$ & $(16.70)$ & $(8.58)$ & $(15.54)$ & $(27.70)$ \\
\hline \multirow[t]{2}{*}{ Change in total income } & -10.53 & -5.29 & -8.25 & 1.94 & 3.98 & 3.00 \\
\hline & $(21.51)$ & $(22.04)$ & $(16.66)$ & $(9.01)$ & $(17.22)$ & $(28.55)$ \\
\hline \multirow[t]{2}{*}{ Transitory shocks } & -14.98 & -15.19 & -16.75 & -17.71 & -18.02 & -16.85 \\
\hline & $(8.50)$ & $(9.32)$ & $(8.66)$ & $(9.70)$ & $(6.64)$ & $(12.61)$ \\
\hline \multirow[t]{2}{*}{ Pubic Aid received } & 0.47 & 0.30 & 0.01 & 0.05 & 0.00 & 0.00 \\
\hline & $(1.09)$ & $(0.61)$ & $(0.02)$ & $(0.14)$ & 0.00 & 0.00 \\
\hline \multirow[t]{2}{*}{ Gifts from friends\&relatives } & 0.78 & 0.61 & 0.22 & 0.16 & 0.27 & 0.05 \\
\hline & $(1.31)$ & $(1.60)$ & $(0.68)$ & $(0.35)$ & $(0.68)$ & $(0.17)$ \\
\hline \multirow[t]{2}{*}{ Gifts to friends\&relatives } & 0.78 & 0.49 & 0.31 & 0.48 & 0.92 & 0.22 \\
\hline & $(1.32)$ & $(1.01)$ & $(0.57)$ & $(0.98)$ & $(1.44)$ & $(0.57)$ \\
\hline \multirow[t]{2}{*}{ Net transfers } & 0.49 & 0.16 & -0.19 & -0.23 & -0.62 & -0.20 \\
\hline & $(2.54)$ & $(1.72)$ & $(0.62)$ & $(0.96)$ & $(1.18)$ & $(0.63)$ \\
\hline \multirow[t]{2}{*}{ Cattle (head count) } & 0.91 & 0.60 & 0.02 & 0.44 & 0.55 & 0.23 \\
\hline & $(1.58)$ & $(0.86)$ & $(0.08)$ & $(1.18)$ & $(1.06)$ & $(0.46)$ \\
\hline \multirow[t]{2}{*}{ Sheep (head count) } & 0.59 & 0.49 & 1.31 & 1.05 & 0.44 & 0.32 \\
\hline & $(2.62)$ & $(0.84)$ & $(1.16)$ & $(1.28)$ & $(0.61)$ & $(0.93)$ \\
\hline \multirow[t]{2}{*}{ Goat (head count) } & 1.80 & 0.90 & 1.56 & 1.99 & 0.48 & 0.79 \\
\hline & $(2.62)$ & $(0.84)$ & $(1.16)$ & $(1.28)$ & $(0.61)$ & $(0.93)$ \\
\hline \multirow[t]{2}{*}{ Livestock } & 46.21 & 49.96 & 10.45 & 25.07 & 22.98 & 8.25 \\
\hline & $(65.79)$ & $(123.23)$ & $(7.90)$ & $(46.85)$ & $(41.72)$ & $(16.45)$ \\
\hline \multirow[t]{2}{*}{ Grain stock } & 4.32 & 1.42 & 6.05 & 2.95 & 2.12 & 1.88 \\
\hline & $(8.22)$ & $(2.34)$ & (9.11) & $(4.36)$ & $(7.78)$ & $(11.84)$ \\
\hline \multirow[t]{2}{*}{ Total labor use (hours) } & 2132.64 & 2467.12 & 5222.17 & 2977.49 & 7142.18 & 4109.45 \\
\hline & $(1464.21)$ & $(1353.62)$ & $(4231.70)$ & $(2095.77)$ & $(4995.85)$ & $(2563.73)$ \\
\hline \multirow[t]{2}{*}{ Familiy labor use (hours) } & 2061.48 & 2381.78 & 4583.92 & 2849.43 & 5678.06 & 3456.62 \\
\hline & $(1457.16)$ & $(1331.09)$ & $(3628.25)$ & $(2017.27)$ & $(3737.53)$ & $(2169.65)$ \\
\hline \multirow[t]{2}{*}{ household size (adult equivalents) } & 7.43 & 7.60 & 9.75 & 8.54 & 12.71 & 8.21 \\
\hline & $(4.62)$ & $(4.04)$ & $(5.45)$ & $(5.23)$ & $(7.96)$ & $(5.37)$ \\
\hline \multirow[t]{2}{*}{ household size (head count) } & 9.78 & 9.93 & 13.11 & 11.64 & 15.95 & 11.07 \\
\hline & $(6.15)$ & $(5.52)$ & $(7.45)$ & $(7.29)$ & $(10.75)$ & $(7.41)$ \\
\hline
\end{tabular}

Standard deviations are in parentheses

All variables expressed in CFA 1'000 per adult equivalent per annum, unless stated otherwise

Net transfers are gifts from friends/relative plus Public aid minus gifts to relatives/friends 
Table 3: Summary Statistics by Quintile of Transitory Shocks

(1) (2) (3) (4)

\begin{tabular}{|c|c|c|c|c|c|c|c|}
\hline & (1) & $(2)$ & (3) & (4) & (3) & (b) & \\
\hline $\begin{array}{l}\text { quintile } \\
1\end{array}$ & Calories & dCalories & Cons & dCons & Crop income & dCrop income & Livestock \\
\hline Mean & 2158.251 & -2544.926 & 21.315 & -20.010 & 13.758 & -27.709 & 38.365 \\
\hline Median & 2001.060 & -2387.595 & 19.853 & -18.526 & 11.717 & -24.857 & 12.177 \\
\hline $\begin{array}{l}\text { St dev } \\
2\end{array}$ & 938.353 & 1631.740 & 10.998 & 15.610 & 11.865 & 16.625 & 61.016 \\
\hline Mean & 1894.161 & -925.065 & 19.457 & -5.803 & 10.997 & -11.605 & 18.772 \\
\hline Median & 1568.513 & -1069.889 & 15.433 & -7.588 & 9.590 & -12.177 & 9.283 \\
\hline $\begin{array}{l}\text { St dev } \\
3\end{array}$ & 1232.924 & 1509.200 & 14.523 & 15.450 & 7.195 & 5.348 & 31.493 \\
\hline Mean & 1681.902 & -283.730 & 15.929 & -0.652 & 18.408 & -1.139 & 16.916 \\
\hline Median & 1600.602 & -253.985 & 14.507 & -1.432 & 15.201 & -1.154 & 3.990 \\
\hline $\begin{array}{l}\text { St dev } \\
4\end{array}$ & 606.982 & 800.109 & 6.423 & 6.998 & 13.877 & 3.892 & 42.564 \\
\hline Mean & 2225.538 & 249.782 & 21.577 & 5.556 & 21.742 & 6.593 & 19.947 \\
\hline Median & 2017.357 & 408.834 & 19.750 & 6.260 & 19.163 & 6.903 & 6.800 \\
\hline $\begin{array}{l}\text { St dev } \\
5\end{array}$ & 1076.802 & 1051.121 & 10.783 & 9.791 & 12.327 & 3.865 & 40.367 \\
\hline Mean & 3220.875 & 1380.993 & 31.005 & 16.838 & 36.895 & 22.454 & 26.691 \\
\hline Median & 2951.697 & 1333.917 & 27.215 & 14.497 & 30.198 & 17.926 & 8.825 \\
\hline $\begin{array}{l}\text { St dev } \\
\text { Total }\end{array}$ & 1550.737 & 1273.600 & 14.516 & 12.160 & 24.110 & 17.905 & 45.839 \\
\hline Mean & 2236.145 & -404.086 & 21.915 & -0.899 & 20.360 & -2.281 & 24.229 \\
\hline Median & 1995.695 & -271.333 & 18.942 & -0.277 & 16.289 & -1.246 & 7.674 \\
\hline St dev & 1237.788 & 1827.425 & 12.771 & 17.346 & 17.415 & 20.384 & 45.770 \\
\hline
\end{tabular}

Levels and livestock are values before the shock.

All variables are expressed in CFA 1'000 per adult equivalent per annum 
Table 4: Determinants of Income

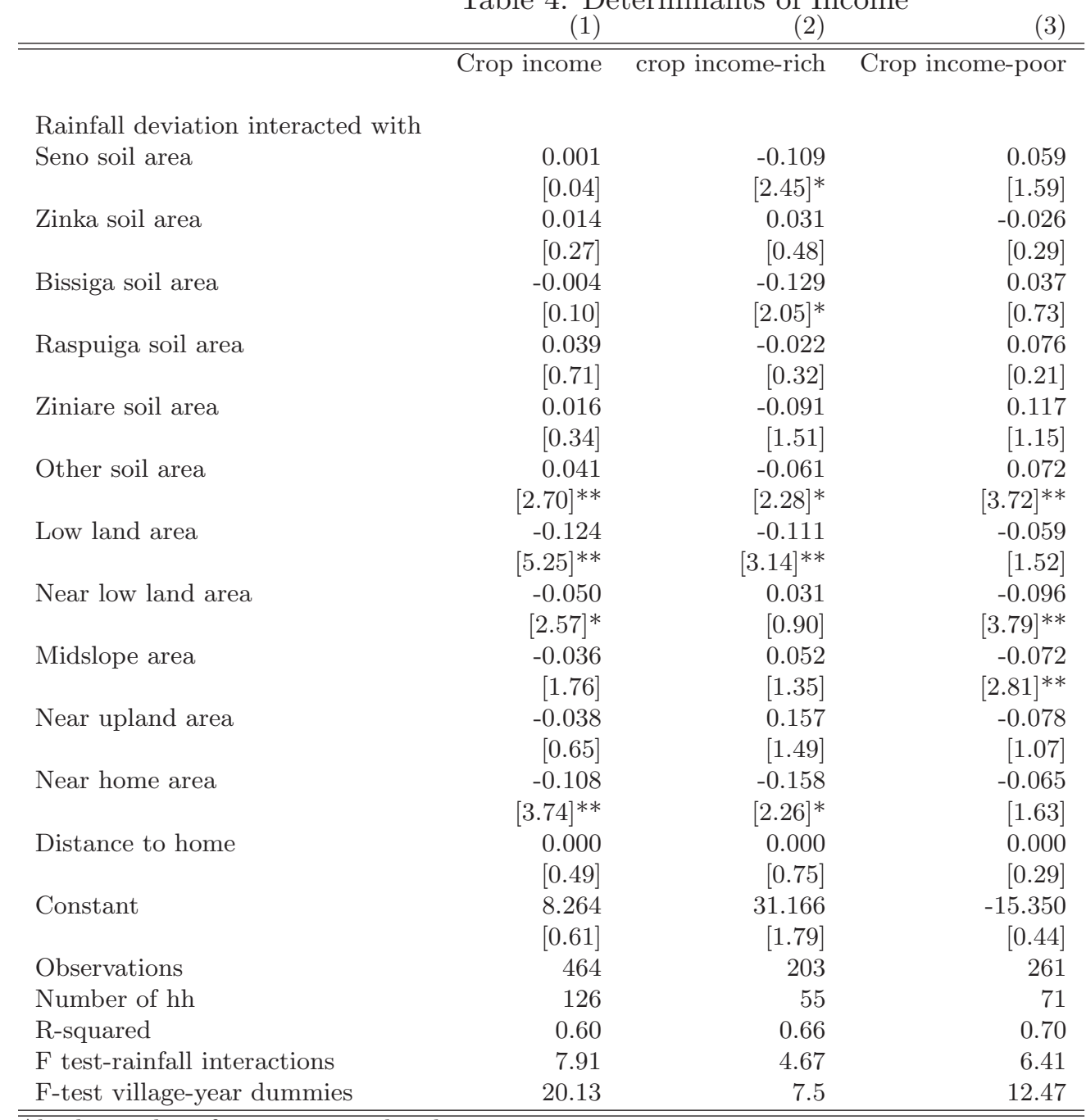

Absolute value of $t$ statistics in brackets

* significant at $5 \% ; * *$ significant at $1 \%$

Regressions also include demographic variables (adult males, adult females, boys, girls, household size, age of household head and age age of household head squared) but coefficients are not reported

Household and village-year fixed effects are controlled for 
Table 5: Magnitude of income shocks

\begin{tabular}{lrrr}
\hline \hline Villages & Shock nature & Crop income & Total income \\
& & & \\
Woure & Aggregate & 1.787 & 2.384 \\
& Idiosyncratic & 0.585 & 0.579 \\
& & & \\
Kolbila & Aggregate & 2.179 & 2.307 \\
& Idiosyncratic & 0.562 & 0.569 \\
& Aggregate & 2.179 & 2.307 \\
Ouonon & Idiosyncratic & 0.520 & 0.490 \\
& Aggregate & 1.113 & 0.736 \\
Koho & Idiosyncratic & 0.336 & 0.303 \\
& Aggregate & 1.819 & 1.691 \\
& Idiosyncratic & 0.506 & 0.472 \\
Sayero & & & \\
& Aggregate & 0.66 & 0.56 \\
\hline \hline Coefficients of variation of each type shocks.
\end{tabular}

Coefficients of variation of each type shocks. 
Table 6: Determinants of Consumption

\begin{tabular}{|c|c|c|c|c|c|}
\hline & $(1)$ & $(2)$ & (3) & (4) & $(5)$ \\
\hline Permanent income & $\begin{array}{r}0.010 \\
{[0.126]}\end{array}$ & & & & \\
\hline Transitory income & $\begin{array}{r}0.541 \\
{[0.131]^{* * *}}\end{array}$ & & $\begin{array}{r}0.644 \\
{[0.060]^{* * *}}\end{array}$ & $\begin{array}{r}0.505 \\
{[2.12]^{* *}}\end{array}$ & \\
\hline Unexplained income & $\begin{array}{r}0.487 \\
{[0.136]^{* * *}}\end{array}$ & & $\begin{array}{r}0.440 \\
{[0.054]^{* * *}}\end{array}$ & $\begin{array}{r}0.420 \\
{[4.13]^{* * *}}\end{array}$ & \\
\hline Rich & & & & & \\
\hline Permanent income & & $\begin{array}{r}0.030 \\
{[0.158]}\end{array}$ & & & \\
\hline Transitory income & & $\begin{array}{r}0.567 \\
{[0.165]^{* * *}}\end{array}$ & & & $\begin{array}{r}0.530 \\
{[2.05]^{* *}}\end{array}$ \\
\hline Unexplained income & & $\begin{array}{r}0.403 \\
{[0.178]^{* *}}\end{array}$ & & & $\begin{array}{l}0.212 \\
{[1.37]}\end{array}$ \\
\hline Poor & & & & & \\
\hline Permanent income & & $\begin{array}{r}0.147 \\
{[0.239]}\end{array}$ & & & \\
\hline Transitory income & & $\begin{array}{r}0.589 \\
{[0.199]^{* * *}}\end{array}$ & & & $\begin{array}{r}0.795 \\
{[2.55]^{* *}}\end{array}$ \\
\hline Unexplained income & & $\begin{array}{r}0.571 \\
{[0.187]^{* * *}}\end{array}$ & & & $\begin{array}{r}0.651 \\
{[4.61]^{* * *}}\end{array}$ \\
\hline wealthy & & $\begin{array}{r}-1.543 \\
{[3.378]}\end{array}$ & & & \\
\hline Constant & $\begin{array}{r}4.199 \\
{[18.293]}\end{array}$ & $\begin{array}{r}2.351 \\
{[18.833]}\end{array}$ & $\begin{array}{r}70.859 \\
{[30.953]^{* *}}\end{array}$ & $\begin{array}{r}33.586 \\
{[0.19]}\end{array}$ & $\begin{array}{r}-1.312 \\
{[0.01]}\end{array}$ \\
\hline R-squared & 0.21 & 0.21 & 0.42 & 0.34 & 0.38 \\
\hline
\end{tabular}

Standard errors in brackets

* significant at $10 \%$; $*$ significant at $5 \%,{ }^{* * *}$ significant at $1 \%$

Income in columns 1 and 2 is net of imputed value of household labor

Regressions also include demographic variables (adult males, adult females, boys, girls, household size, age of household head and age age of household head squared) but coefficients are not reported

Columns 1, 2 and 3 use the full sample. Columns 4 and 5 use the sample of directly observed consumption

Household fixed effects are controlled for. 


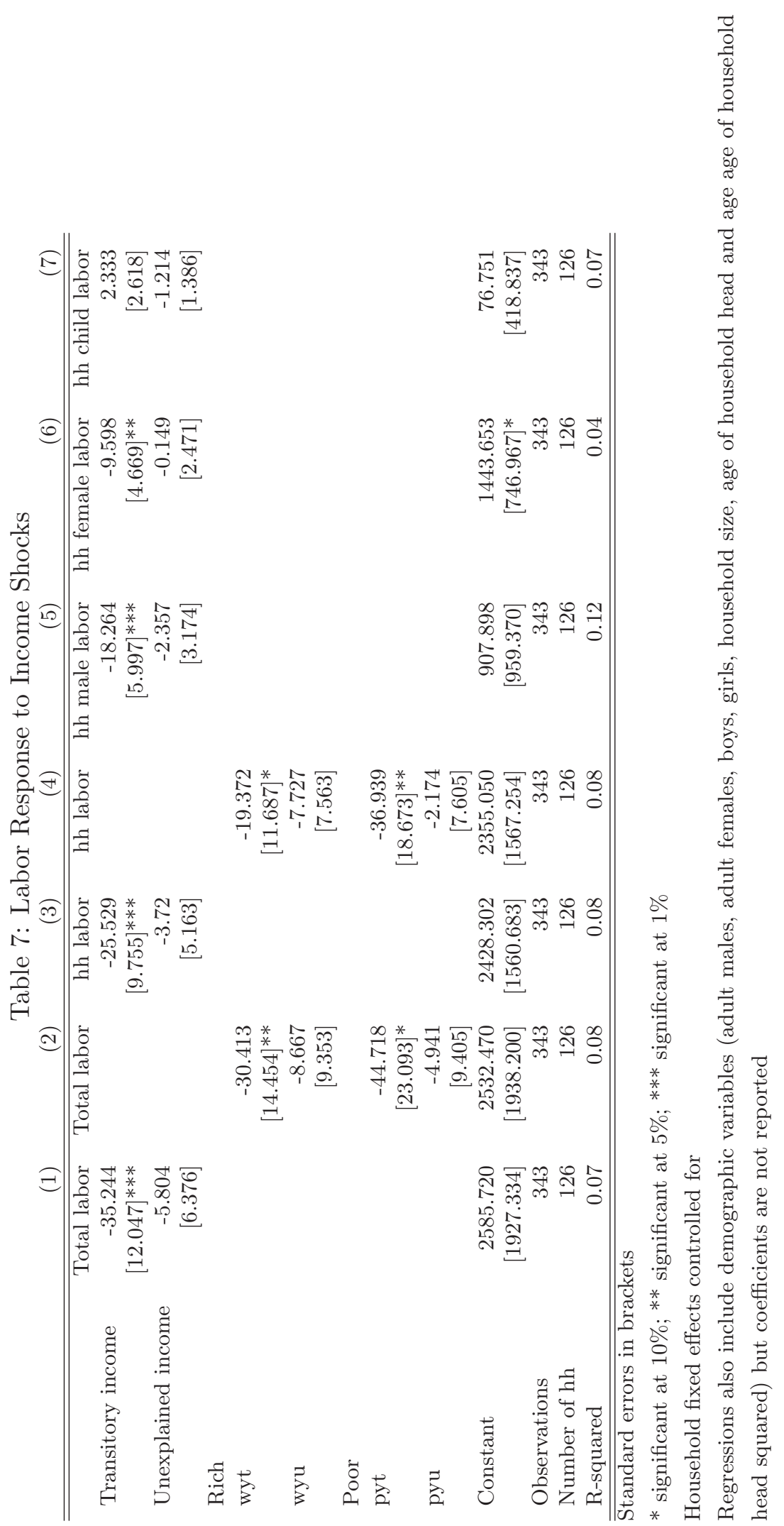


Table 8: Determinants of changes in Grain and Livestock Holdings

\begin{tabular}{|c|c|c|c|c|}
\hline & $(1)$ & $(2)$ & $(3)$ & (4) \\
\hline & \multicolumn{2}{|c|}{ grain storage } & \multicolumn{2}{|c|}{ livestock sales } \\
\hline \multirow[t]{2}{*}{ Permanent income } & 0.327 & & -0.027 & \\
\hline & {$[0.152]^{* *}$} & & {$[0.004]^{* * *}$} & \\
\hline \multirow[t]{2}{*}{ Transitory income } & 0.275 & & -0.004 & \\
\hline & {$[0.077]^{* * *}$} & & {$[0.002]^{* *}$} & \\
\hline \multirow[t]{2}{*}{ Unexplained income } & 0.043 & & -0.002 & \\
\hline & {$[0.055]$} & & {$[0.002]$} & \\
\hline \multicolumn{5}{|l|}{ Rich } \\
\hline \multirow[t]{2}{*}{ Permanent income } & & 0.353 & & -0.028 \\
\hline & & {$[0.161]^{* *}$} & & {$[0.005]^{* * *}$} \\
\hline \multirow[t]{2}{*}{ Transitory income } & & 0.502 & & -0.003 \\
\hline & & {$[0.106]^{* * *}$} & & {$[0.003]$} \\
\hline \multirow[t]{2}{*}{ Unexplained income } & & -0.067 & & -0.010 \\
\hline & & {$[0.086]$} & & {$[0.003]^{* * *}$} \\
\hline \multicolumn{5}{|l|}{ Poor } \\
\hline \multirow[t]{2}{*}{ Permanent income } & & 0.227 & & -0.013 \\
\hline & & {$[0.243]$} & & {$[0.007]^{*}$} \\
\hline \multirow[t]{2}{*}{ Transitory income } & & 0.067 & & -0.001 \\
\hline & & [0.109] & & {$[0.003]$} \\
\hline \multirow[t]{2}{*}{ Unexplained income } & & 0.053 & & 0.006 \\
\hline & & {$[0.075]$} & & {$[0.002]^{* * *}$} \\
\hline \multirow[t]{2}{*}{ Constant } & -181.903 & -194.011 & 1.954 & 1.613 \\
\hline & {$[36.283]^{* * *}$} & {$[36.518]^{* * *}$} & {$[0.489]^{* * *}$} & {$[0.480]^{* * *}$} \\
\hline Observations & 340 & 340 & 464 & 464 \\
\hline Number of hh & 126 & 126 & 126 & 126 \\
\hline R-squared & 0.38 & 0.41 & 0.23 & 0.28 \\
\hline
\end{tabular}

Absolute value of $\mathrm{t}$ in brackets

* significant at $10 \%$; ** significant at $5 \%, * * *$ significant at $1 \%$

Household fixed effects controlled for

Regressions also include demographic variables (adult males, adult females, boys, girls, household size, age of household head and age age of household head squared) but coefficients are not reported 
Table 9: Determinants of Saving

\begin{tabular}{lrr} 
& $(1)$ & $(2)$ \\
\hline \hline & & for rich \\
Permanent income & 0.457 & 0.555 \\
& {$[0.051]^{* * *}$} & {$[0.076]^{* * *}$} \\
Transitory income & 0.092 & 0.099 \\
& {$[0.092]$} & {$[0.117]$} \\
Unexplained income & 0.322 & 0.370 \\
& {$[0.055]^{* * *}$} & {$[0.087]^{* * *}$} \\
Income Variance & 0.023 & 0.021 \\
& {$[0.003]^{* * *}$} & {$[0.004]^{* * *}$} \\
Permanent income & & for poor \\
& & 0.397 \\
Transitory income & & {$[0.102]^{* * *}$} \\
& & 0.115 \\
Unexplained income & & {$[0.120]$} \\
& & 0.288 \\
Income Variance & & {$[0.076]^{* * *}$} \\
& & 0.023 \\
age of hh head & 0.460 & {$[0.005]^{* * *}$} \\
& {$[0.305]$} & 0.490 \\
hh head age sq. & -0.006 & {$[0.310]$} \\
& {$[0.003]^{*}$} & -0.006 \\
Rich & & $-0.003]^{*}$ \\
& & {$[4.546$} \\
Constant & -35.031 & -33.467 \\
& {$[7.986]^{* * *}$} & {$[8.232]^{* * *}$} \\
Observations & 392 & 392 \\
R-squared & 0.47 & 0.47 \\
\hline \hline Stal & &
\end{tabular}

Standard errors in brackets

* significant at $10 \%$; ${ }^{*}$ significant at $5 \%, * * *$ significant at $1 \%$ 


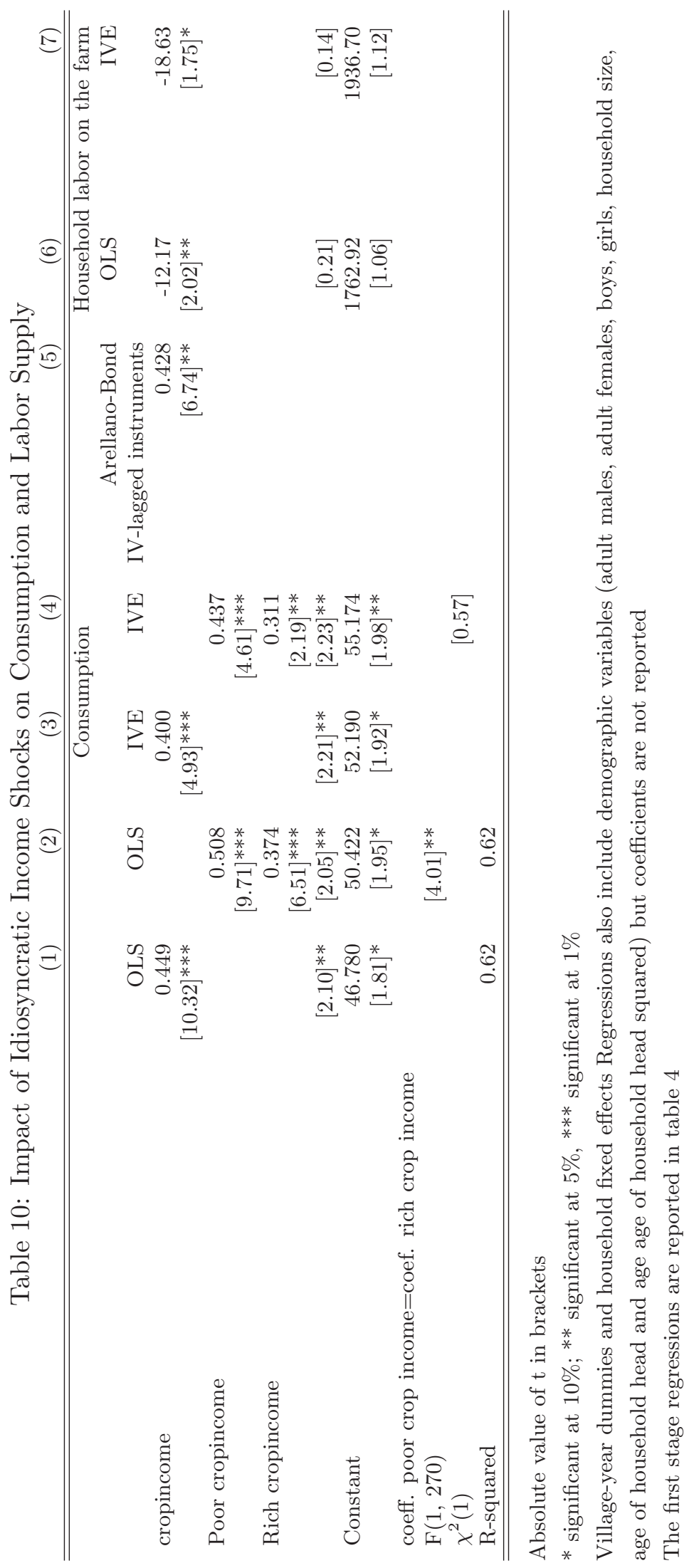


Table 11: Restricted Version of Full Insurance Test, No Village-year Fixed Effects

\begin{tabular}{lrr} 
& $(1)$ & $(2)$ \\
\hline \hline & IVE & IVE \\
cropincome & 0.380 & \\
& {$[4.16]^{* * *}$} & \\
Poor cropincome & & 0.439 \\
& & {$[3.65]^{* * *}$} \\
Rich cropincome & 0.304 \\
& & {$[2.24]^{* *}$} \\
Constant & 44.266 & 47.224 \\
& {$[1.41]$} & {$[1.51]$} \\
coefficient(vyrfe)-coefficient(no vyrfe) & & \\
Crop income & -0.020 & \\
& 0.122 & \\
Poor & & 0.002 \\
& & 0.452 \\
Rich & & -0.007 \\
& & 0.138 \\
Observations & 395.0 & 395.0 \\
Number of hh & 112.0 & 112.0 \\
R-squared & & \\
\hline \hline
\end{tabular}

Absolute value of $\mathrm{t}$ in brackets

* significant at $10 \% ; * *$ significant at $5 \%, * * *$ significant at $1 \%$

Household fixed effects controlled for

Regressions also include demographic variables (adult males, adult females, boys, girls, household size, age of household head and age age of household head squared) but coefficients are not reported

The first stage is regression 1 but without the village-year dummy variables $\gamma_{t v}$ 
Table 12: Determinants of Net Transfers Received

\begin{tabular}{|c|c|c|c|c|}
\hline & (1) & (2) & (3) & (4) \\
\hline & OLS & IVE & OLS & IVE \\
\hline \multirow[t]{2}{*}{ cropincome } & -0.005 & -0.010 & & \\
\hline & {$[0.97]$} & {$[0.90]$} & & \\
\hline \multirow[t]{2}{*}{ Poor cropincome } & & & -0.012 & $\begin{array}{r}-0.009 \\
-0.711\end{array}$ \\
\hline & & & {$[1.79]$} & {$[0.71]$} \\
\hline \multirow[t]{2}{*}{ Rich cropincome } & & & 0.003 & -0.011 \\
\hline & & & {$[0.42]$} & {$[0.59]$} \\
\hline \multirow{2}{*}{ Constant } & 1.366 & 1.382 & 0.979 & 1.650 \\
\hline & {$[0.42]$} & {$[0.41]$} & {$[0.30]$} & {$[0.47]$} \\
\hline Observations & 399 & 399 & 399 & 399 \\
\hline Number of hh & 114 & 114 & 114 & 114 \\
\hline R-squared & 0.570 & & 0.580 & \\
\hline
\end{tabular}

Absolute value of $\mathrm{t}$ in brackets

* significant at $10 \% ; * *$ significant at $5 \%, * * *$ significant at $1 \%$

Village-year fixed effects and household fixed effects Regressions also include demographic variables (adult males, adult females, boys, girls, household size, age of household head and age age of household head squared) but coefficients are not reported

The first stage regressions are reported in table 4 . 
Table 13: Estimates of Net Changes in Grain and Livestock

\begin{tabular}{lrrrr} 
& $(1)$ & $(2)$ & $(3)$ & $(4)$ \\
\hline \hline \multirow{2}{*}{ income } & grain storage & \multicolumn{3}{c}{ livestock sales } \\
& 0.413 & & -0.02 & \\
Poor income & {$[5.22]^{* * *}$} & & {$[5.20]^{* * *}$} & -0.015 \\
& & 0.264 & & {$[1.08]$} \\
Rich income & & {$[0.87]$} & & -0.02 \\
& & 0.42 & & {$[5.36]^{* * *}$} \\
Constant & 16.336 & 22.701 & 2.261 & 2.062 \\
& {$[0.62]$} & {$[0.77]$} & {$[3.91]^{* * *}$} & {$[3.03]^{* * *}$} \\
Observations & 340 & 340 & 464 & 464 \\
Number of hh & 112 & 112 & 126 & 126 \\
\hline \hline Absolvt
\end{tabular}

Absolute value of $t$ in brackets

* significant at $10 \%$;* significant at $5 \%, * * *$ significant at $1 \%$

Village-year fixed effects and household fixed effects Regressions also include demographic variables (adult males, adult females, boys, girls, household size, age of household head and age age of household head squared) but coefficients are not reported

The first stage regressions are reported in table 4 . 
Table 14: Determinants of Age of Livestock at Sale

\begin{tabular}{lrrrr} 
& $(1)$ & $(2)$ & $(3)$ & $(4)$ \\
\hline \hline Crop income & 0.008 & 0.003 & 0.009 & 0.009 \\
& {$[0.53]$} & {$[0.24]$} & {$[0.25]$} & {$[0.27]$} \\
adult males & 0.171 & 0.214 & 0.124 & 0.174 \\
& {$[2.47]^{* *}$} & {$[3.02]^{* * *}$} & {$[0.95]$} & {$[1.26]$} \\
adult females & -0.067 & -0.149 & -0.469 & -0.634 \\
& {$[1.40]$} & {$[2.39]^{* *}$} & {$[3.23]^{* * *}$} & {$[3.70]^{* * *}$} \\
age hh head & 0.002 & 0.005 & & \\
& {$[0.28]$} & {$[0.76]$} & & \\
girls & & -0.03 & & -0.159 \\
& & {$[0.69]$} & & {$[1.50]$} \\
boys & & 0.117 & & 0.177 \\
& & {$[2.87]^{* * *}$} & & {$[1.74]^{*}$} \\
Constant & -0.505 & -0.666 & 1.215 & 1.616 \\
& {$[1.58]$} & {$[2.04]^{* *}$} & {$[0.96]$} & {$[1.26]$} \\
Observations & 1331 & 1331 & 1331 & 1331 \\
\hline \hline Obso
\end{tabular}

Absolute value of $\mathrm{t}$ in brackets

$*$ significant at $10 \%$; $* *$ significant at $5 \%,{ }^{* * *}$ significant at $1 \%$

Columns 1-2: Village-year-animal type-animal sex fixed effects fixed effects

Columns 3-4: Village-year-animal type-animal sex fixed effects and household fixed effects Income is instrumented as explained in regression 1. 

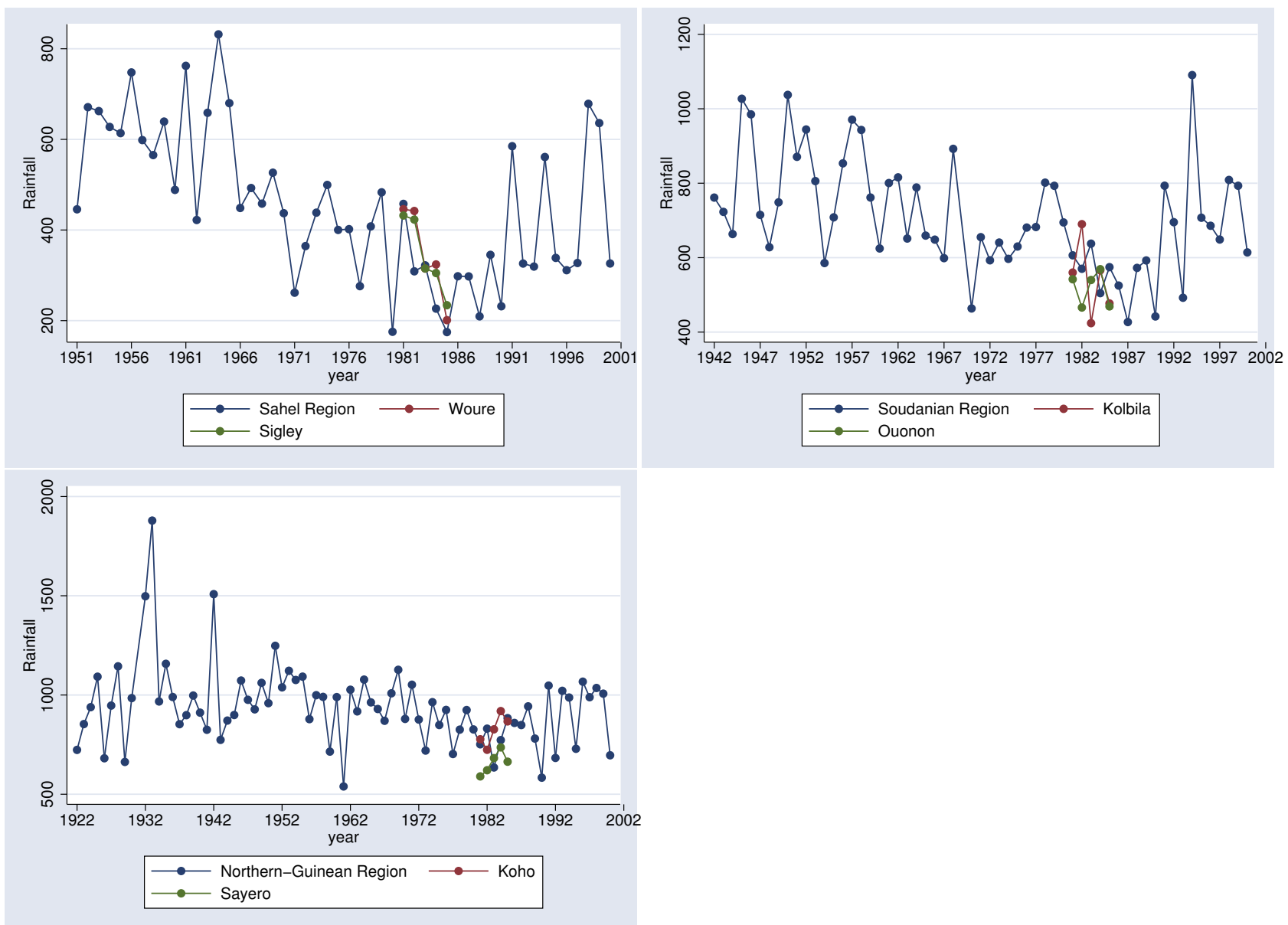

Figure 1: Long run rainfall 

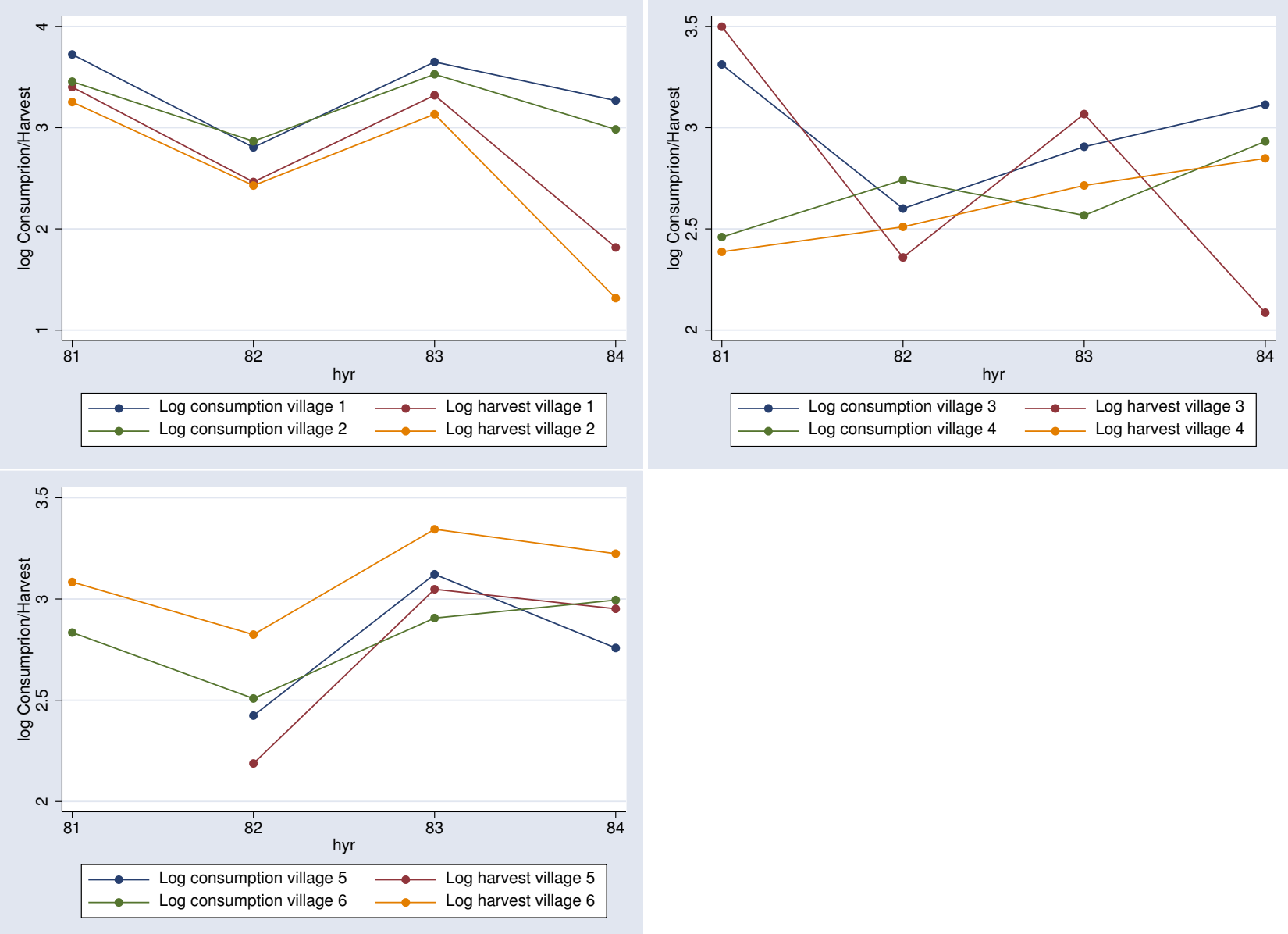

Figure 2: Village income and consumption growth 